\title{
UM ESTUDO SOBRE A INFLUÊNCIA DA ARBORIZAÇÃO NA PRAÇA DA AVENIDA NS15 DA QUADRA 307 NORTE
}

A Study on the influence of afforestation in the square of the avenue NS15 from the Block 307 North

Un estudio sobre la influencia de la arborización en la plaza de la Avenida NS15 de la Cuadra 307 Norte

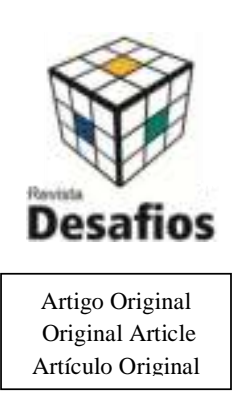

\section{Christine Heerdt $^{* 1}$, Mariela Cristina Ayres de Oliveira ${ }^{1}$}

${ }^{1}$ Curso de Arquitetura e Urbanismo, Universidade Federal do Tocantins, Campus de Palmas, Tocantins, Brasil.

*Correspondência: Curso de Arquitetura e Urbanismo, Universidade Federal do Tocantins, Av. NS 15, 109 Norte, Palmas, Tocantins, Brasil.CEP: 77.010-090.e-mail: cheerdt10@hotmail.com

\section{RESUMO}

Uma arborização adequada contribui para a diminuição do desconforto gerado pelo calor. O estudo foi realizado em quadra residencial de uso misto da região norte da cidade de Palmas. O objetivo principal do trabalho foi avaliar a influência da vegetação, principalmente das árvores do cerrado, no clima da praça da avenida NS 15, na 307 Norte. Com o inventário das árvores da região fez-se a escolha adequada das espécies as quais foram feitas medições da temperatura ambiente, de ar e de globo, temperatura de superfície, umidade relativa do ar, luminosidade, temperatura e velocidade do vento verificando o comportamento dos fatores que compõem o clima e o conforto térmico em cada situação, além de campo aberto para efeito de comparação. Com os dados obtidos foram realizadas simulações computacionais através do programa Envi-Met, detectando zonas de influência da arborização na área estudada e seu entorno. Com isso, concluiu-se a relevância da vegetação para a obtenção de ambientes confortáveis termicamente, pois colabora com a estabilidade microclimática, com a redução da insolação direta, redução da velocidade dos ventos, desempenhando um importante papel na melhoria da condição ambiental das cidades e melhora na qualidade de vida de seus habitantes.

Palavras-chave: arborização, microclima, conforto térmico

\section{ABSTRACT}

An adequate afforestation contributes to the discomfort reduction generated by heat. The present study was conducted in a residential block of mixed use in the northern region of the Palmascity. The aim of this work was to evaluate the vegetation influence, mainly cerrado trees, in the climate of the public square of the NS 15 avenue in 307 north. With the region trees inventory, the proper choice of the tree species was conducted. The measurements performed were: ambient, air and globe temperature, surface temperature, relative air humidity, luminosity, temperature and wind speed. With these variables, we were able to verify the behavior of the factors that make up the climate and thermal comfort in each situation. In addition, an open ground was used for comparison purposes.Computational simulations were carried out through the Envi-Met program, detecting afforestation influence zones in the studied area and its surroundings. Therefore, we highlight the vegetation relevance to get a thermally comfortable environment, once it collaborates with the microclimate stability, direct insolation reduction, lower winds speed, playing an important role in the cities environmental condition improvement and life quality.

Keywords: afforestation, microclimate, thermal comfort

\section{RESUMEN}

Una arborización adecuada contribuye para la disminución de laincomodidad generado por el calor.El estudio fue realizado en cuadra residencial de uso mixto de la región norte de la ciudad de Palmas.El objetivo principal del trabajo fue evaluar la influencia de la vegetación, principalmente de los árboles del Cerrado, en el clima de la plaza de la avenida NS 15, en la 307 Norte.Con el inventario de los árboles de la región se hizo la elección 
adecuada de las especies las cuales fueron hechas medición de la temperatura ambiente, de aire y de globo,temperatura de superficie, humedad relativa del aire, luminosidad, temperatura y velocidad del viento verificando el comportamiento de los factores que componen el clima y el conforto térmico en cada situación, además de campo abierto para efecto de comparación. Con los datos obtenidos fueron realizadas simulaciones por ordenador a través del programa Envi-Met, detectando zonas de influencia de la arborización en el área estudiada y su entorno. Con eso, se concluyó la relevancia de la vegetación para la obtención de ambientes confortables térmicamente, pues colabora con la estabilidad micro climática, con la reducción de la insolación directa, reducción de la velocidad de los vientos, desempeñando un importante papel en la mejoría de la condición ambiental de las ciudades y mejora en la calidad de vida de sus habitantes.

Descriptores: árboles, el microclima, el confort térmico

\section{INTRODUÇÃO}

A cidade de Palmas, capital do Estado do Tocantins, surgiu no ano de 1989 com a criação do Estado. Localizada na região Norte do Brasil foi a última cidade brasileira a ser planejada no século XX.

A cidade encontra-se em uma região de planície com vegetação predominante de cerrado, caracterizada por savana. Localiza-se entre a Serra do Lajeado, na qual tem altitude média de 700m e o Lago da UHE Lajeado, que possui cota de 212,9m.

O número de unidades de conservação é significativo, 9 (nove) ao todo no município, todos caracterizados por córregos, que possuem microclima diferenciado devido à vegetação mais densa. Dessa maneira verifica-se que o uso de vegetação deve ser mais explorado, para garantir maior conforto aos moradores além de diminuir o consumo de energia para refrigeração de ambientes.

Caracterizada por um clima quente e semiúmido, com quatro meses secos, é conhecida nacionalmente como uma das cidades brasileiras com clima muito hostil, proporcionando à população uma sensação desagradável frente ao intenso calor, principalmente entre os meses de julho a setembro. $\mathrm{O}$ Lago da UHE Lajeado, de acordo com dados climáticos obtidos nos últimos anos, interfere no clima da região. A pluviometria total anual de 1994 a 2001 teve uma média de 1936,5 mm, já nos anos de 2002 a 2005 a média total anual reduziu-se a $1483 \mathrm{~mm}$.

O objeto de estudo do presente trabalho é uma quadra residencial de uso misto da região norte da cidade $(307 \mathrm{~N})$, onde é possível perceber os vários problemas proporcionados por uma má implantação da arborização. A discussão tem como foco principal analisar a relação do microclima do local de estudo com a arborização de cerrado ainda presente.

Diversos autores e estudos comprovam que uma arborização adequada contribui para a diminuição do desconforto gerado pelo calor. SILVA (2009) afirma que além de fornecer sombreamento, a massa arbórea permite a passagem da brisa local e absorve de maneira eficaz a radiação térmica de onda longa sobre as folhas refrescadas pela evaporação, podendo, ainda, canalizar o vento e filtrar o ar.

O projeto tem relevância e impacto social significativo, por sua ação possibilitar um levantamento dos problemas de conforto ambiental nas vias públicas da cidade de Palmas e por sua intenção de propor diretrizes para minimizá-los. O estudo da arborização na cidade justifica-se também pela relevância de se elaborar diretrizes que incentivem o plantio com espécies nativas da região, fator fundamental para a preservação do meio ambiente.

Para a identificação do clima urbano lançouse mão de conceitos de Olgyay (1963), Romero (2000) e Panão (2006), os quais abordam as envolventes que fazem parte do estudo da climatologia urbana e consequentemente as condicionantes que caracterizam o clima em uma cidade. Segundo Olgyay (1963) o estudo da 
climatologia engloba um conjunto de muitas variáveis climatológicas, as quais a todo instante aparecem combinadas, dificultando muitas vezes a determinação de sua importância relativa na interação térmica. Sendo assim, para que se consiga atingir um projeto arquitetônico e urbanístico climaticamente equilibrado, deve-se levar em consideração diversos fatores, tais como temperatura, radiação, efeitos do vento, uma vez que os mesmos afetam as sensações conforto humano. Para Silva (2009) as árvores, bem como as praças vegetadas, parques e bosques, são citados como os melhores reguladores climáticos e são usadas como elementos mitigadores dos efeitos gerados pelas ilhas de calor urbano. Além de proporcionar ambientes para lazer, descanso e recreação bem como para o estabelecimento de um microclima mais confortável, a vegetação contribui de forma significativa, tendendo estabilizar os efeitos do clima sobre seus arredores imediatos e reduzindo os extremos ambientais.

Silva (2009) completa que os atributos da vegetação urbana que afetam o microclima positivamente são alta taxa de absorção e radiação, a baixa capacidade de calor e condutividade termal. Se comparado a estruturas e materiais de construção e a espaços abertos, a redução da temperatura do ar pela transpiração, a menor radiação infravermelha, a redução da velocidade do vento próxima da superfície, a retenção de poeira e poluentes do ar. Gartland (2010) completa ainda que árvores promovem sombras para as superfícies e protegem-nas do calor do sol, mantendo essas superfícies mais frescas e reduzem o calor armazenado por elas.

Por meio da vegetação é possível realizar modificações nas escalas meso e microclimática e atenuar os efeitos das "ilhas de calor", que tendem a se formar no espaço urbano e influenciar nas condições bioclimáticas de cada lugar. Sabe-se que a vegetação pode ser utilizada como um elemento estratégico para a mitigação dos fenômenos relacionados às ondas de calor. Kruger e Minella, 2013, comprovam que espaços arborizados podem contribuir para a obtenção de níveis mais adequados de conforto térmico, com uma diferença de até $1,7^{\circ} \mathrm{C}$ na temperatura do ar e de $5^{\circ} \mathrm{C}$ no índice de conforto UTCI, também sugerindo a complementação de áreas gramadas junto às calçadas ou ainda a utilização de árvores de copa densa.

A pesquisa conta com o apoio do Laboratório de Conforto Ambiental, do curso de Arquitetura e Urbanismo (Campus de Palmas) para realização de medições das variáveis climáticas no espaço urbano e para utilização dos aparelhos necessários para aferição dessas variáveis.

\section{MATERIAIS E MÉTODOS}

A arborização urbana é caracterizada pelo cultivo e manutenção de árvores em área como praças, parques, calçadas de vias públicas e alamedas. É uma atividade de grande importância e por tanto, deveria fazer parte de planos e projetos urbanísticos das cidades.

Além de propiciar sombra, purificar o ar, atrair aves, diminuir a poluição sonora, ser um fator estético e paisagístico, diminuir os impactos das chuvas, a arborização pode exercer papel para a melhora do conforto térmico no microclima a que pertence.

Com esse intuito, a pesquisa sobre a Influência da Arborização na Praça da Avenida NS15 da Quadra 307 Norte, pretende medir o grau de conforto térmico que a massa arbórea do local é capaz de ofertar. 
A quadra 307 norte, também conhecida como Vila União, escolhida para a pesquisa, possui detalhes de ocupação muito interessantes. Embora a cidade tenha sido planejada, a área da Vila União não respeita o planejamento da cidade. Essa área está na região noroeste da cidade, denominada pela Prefeitura Municipal como ARNO's (Áreas Residenciais Noroeste), foi objeto de ocupação irregular realizada à revelia do mercado, feita pelos movimentos de moradia. Com o decorrer do tempo, porém, essa região foi sendo parcialmente regularizada. Inicialmente existiu uma previsão de ocupação desta área por uma população com melhor poder aquisitivo, contudo a ação dos movimentos sociais de luta por moradia ocuparam o lugar e a sua consequente regularização proporcionou que uma população de menor renda pudesse residir em uma região próxima ao centro da cidade. É possível notar que na quadra há uma diversidade de espécies arbóreas o que torna o levantamento das espécies primordial para a pesquisa

A primeira etapa da pesquisa consistiu em revisão bibliográfica dentro da temática arborização e clima, verificando inclusive os estudos mais recentes dentro do tema. Após foi realizado levantamento das características de algumas árvores mais constantes no meio urbano com características de cerrado. Essa classificação deu origem ao inventário da arborização urbana da quadra escolhida, com o nome científico de cada espécie pesquisada, nomes populares, características, usos e imagem da árvore, para facilitar a identificação in loco. Após esse estudo, foi realizada uma pesquisa a campo, georeferenciando através do Google Earth as árvores de toda quadra 307 Norte e identificando-as. Na Figura 1, é possível visualizar esse trabalho.

Figura 1. Identificação das Árvores da Quadra 307 Norte

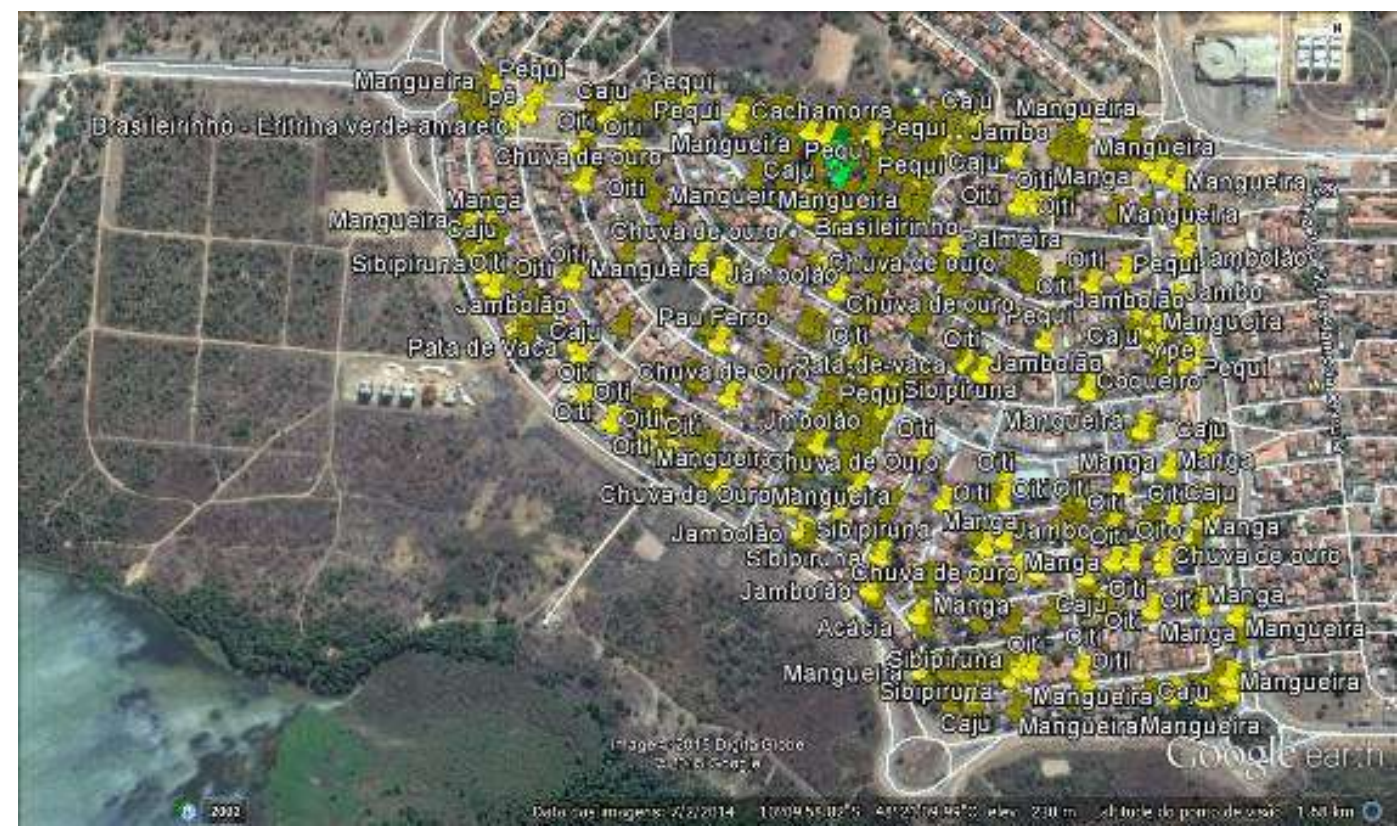

Fonte: Google Earth - modificada pelo autor 
Com as espécies levantadas realizou-se a catalogação das 417 árvores, para saber qual a quantidade de cada, dando origem ao gráfico 1.

Gráfico 1. Espécies Catalogadas na Quadra 307 Norte

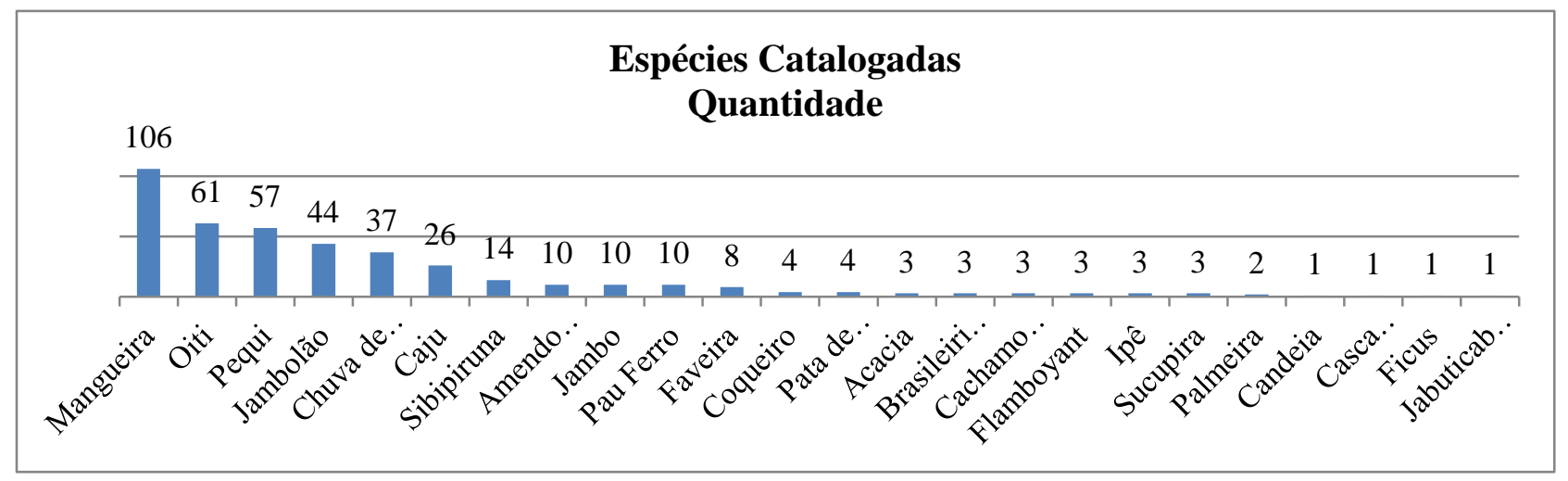

Figura 2. Identificação das Árvores da Quadra 307 Norte, na área escolhida para a medição

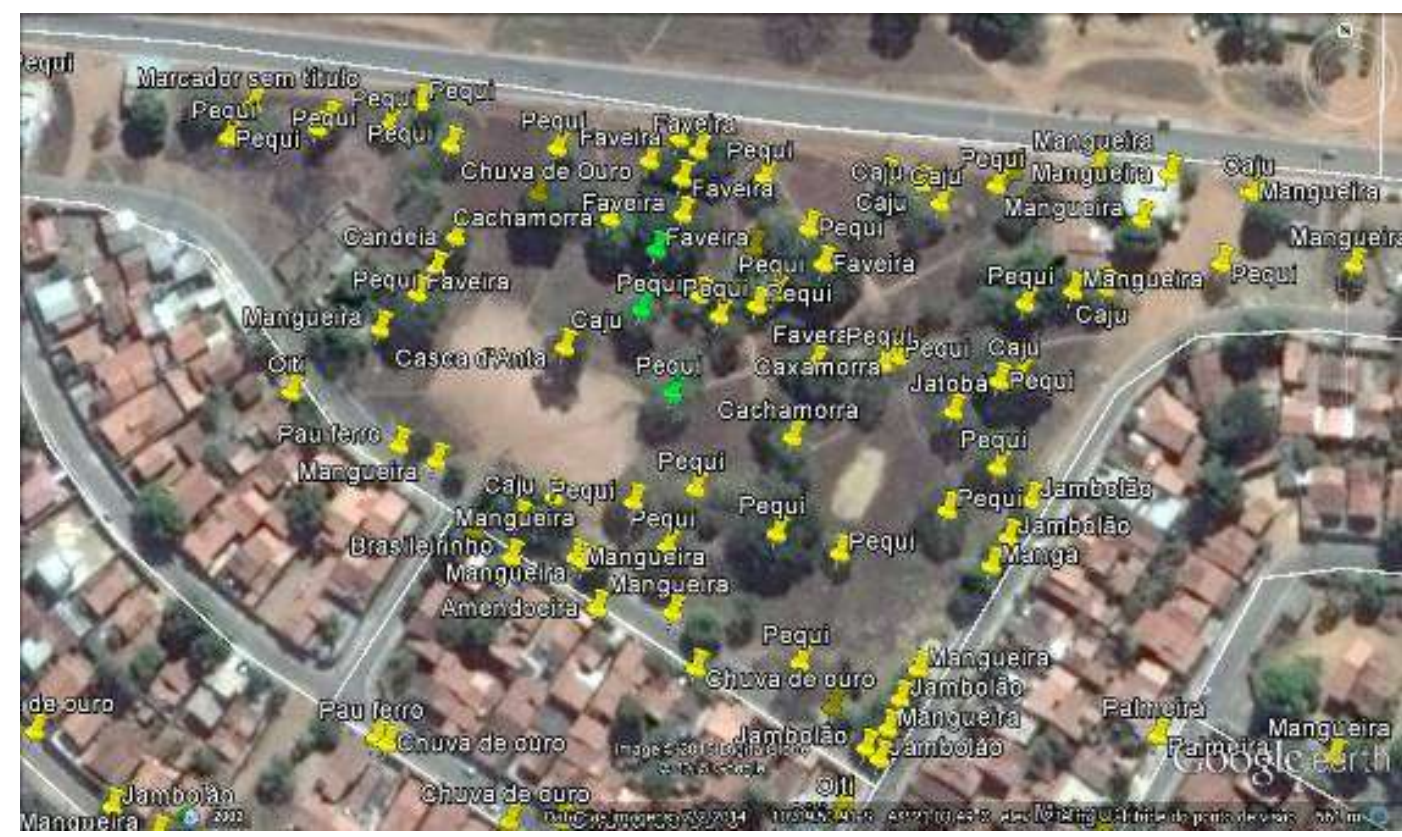

Fonte: Google Earth - modificada pelo autor 
Com esses dados foi possível visualizar a quantidade de árvores por espécie e iniciando-se a escolha de quais seriam realizadas a medição de conforto. Verifica-se no gráfico que a Mangueira e o Oiti são as espécies que mais se apresentam na quadra 307 Norte, porém como não são árvores nativas, a primeira sendo originária do sudeste da Índia e a segunda com origem na Mata Atlântica, descartou-se essas árvores.

Um dos objetivos da escolha da espécie era que sua área de localização tivesse menos interferências possíveis relacionadas ao revestimento do solo, a presença de vegetação, a presença de barreiras, tais como construções, portanto, as árvores selecionadas foram Pequizeiro, Cajueiro e Faveira, como pode se observar na Figura 2.

As espécies escolhidas para o monitoramento microclimático estão identificadas na Figura 3 com a cor verde e estão localizadas em uma área ainda verde com outras árvores nos arredores e sem pavimentação. Além disso, foi escolhido um local próximo às árvores que não sofresse influência direta delas, não sofresse influência pavimentação asfáltica ou calçamento e construções, indicada na Figura 3 com um círculo vermelho.

Figura 3. Árvores identificadas em verde - espécies selecionadas para medição

A localização geográfica de cada espécie está apresentada na tabela a seguir.

Tabela 1. Geolocalização das espécies arbóreas

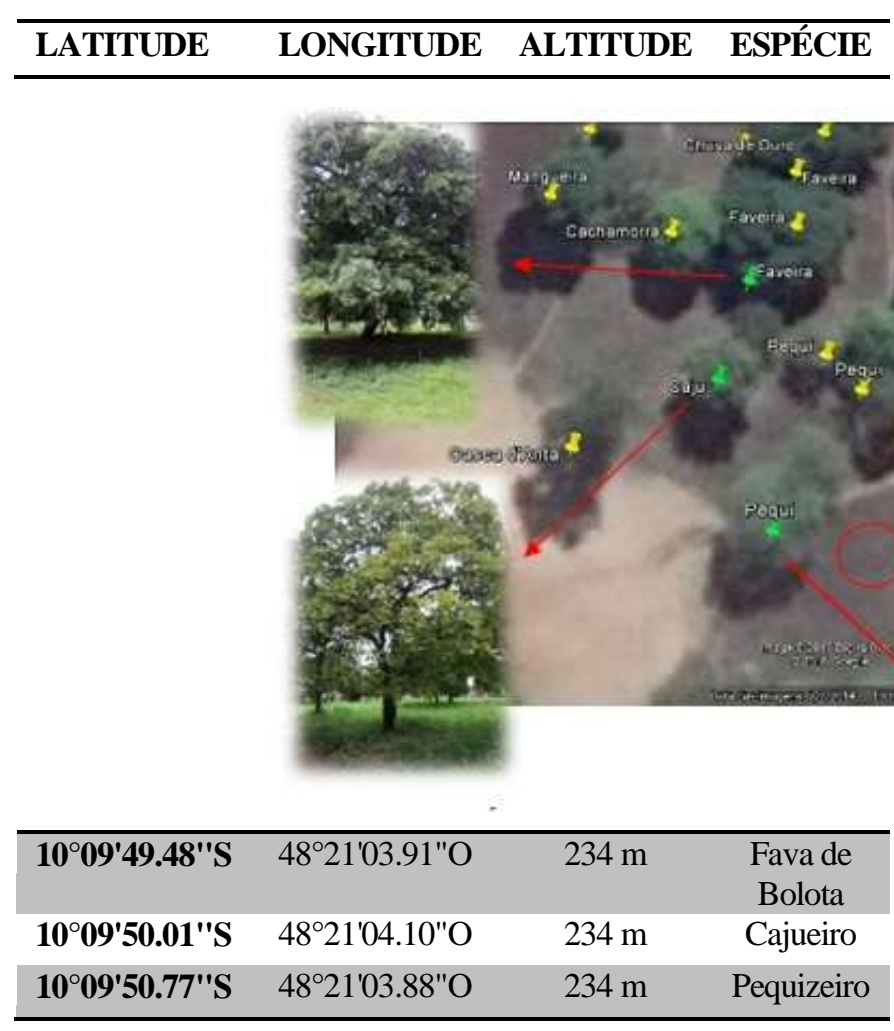

Os monitoramentos microclimáticos foram realizados nas duas estações características da região. Estação chuvosa, sendo o monitoramento realizado nos dias 20, 21 e 22 de dezembro de 2014, e na estação seca, com leituras realizadas nos dias 29 e 30 
as árvores selecionadas e em campo aberto para efeito comparativo.

Os valores obtidos nas leituras foram planilhados e analisados resultando em um valor médio dos três dias de leitura para cada horário e espécie.

\section{RESULTADOS E DISCUSSÃO}

Para facilitar o entendimento dos resultados obtidos foram gerados gráficos com os dados das leituras nas duas estações características da região que demonstram o comportamento dos fatores que compõem o clima e o conforto térmico em cada situação.
Os dados de temperatura ambiente (Gráficos 2 e 3) nos mostram que nas duas estações o comportamento se mantém, sendo diferenciadas apenas pela elevação da temperatura na estação seca. Os valores obtidos em campo aberto se mostraram menos favoráveis do que as leituras sob a copa das árvores porém, com pouca diferença. A espécie que conferiu maior conforto nas duas estações foi a Faveira.

Gráfico 2. Temperatura Ambiente - Estação Chuvosa

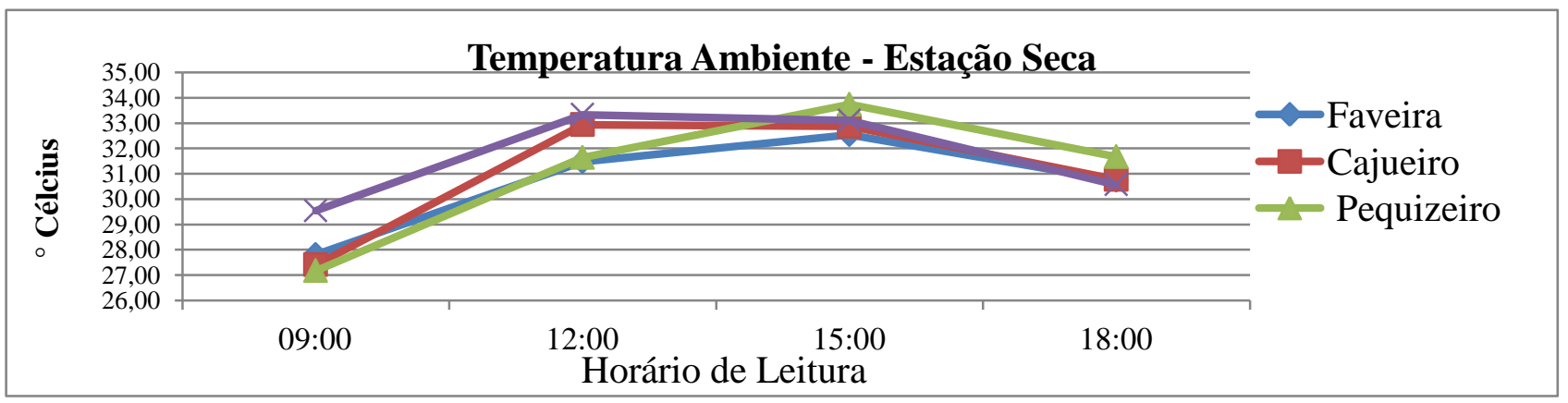

Gráfico 3. Temperatura Ambiente - Estação Seca

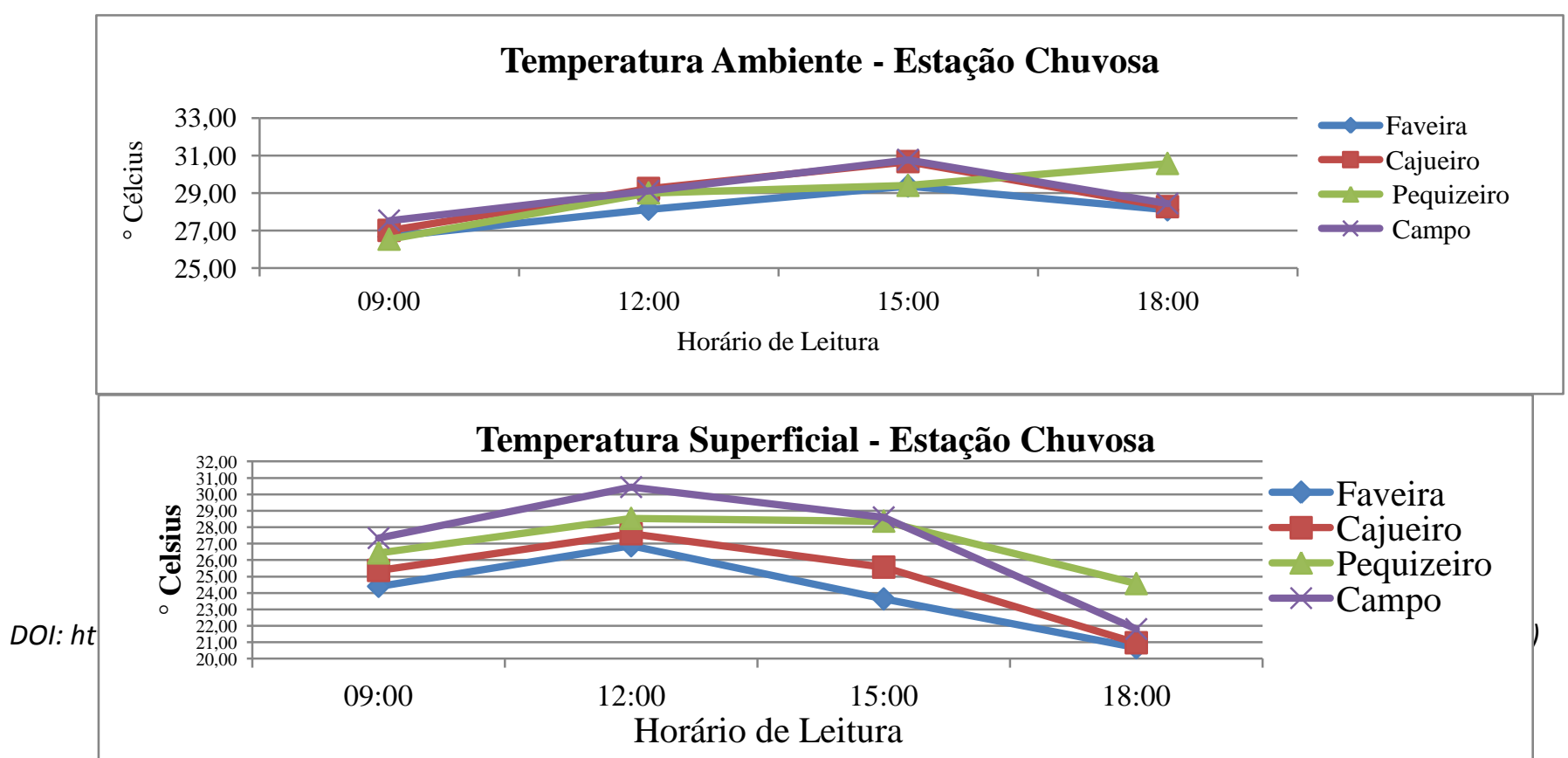


Gráfico 5. Temperatura Superficial - Estação Seca

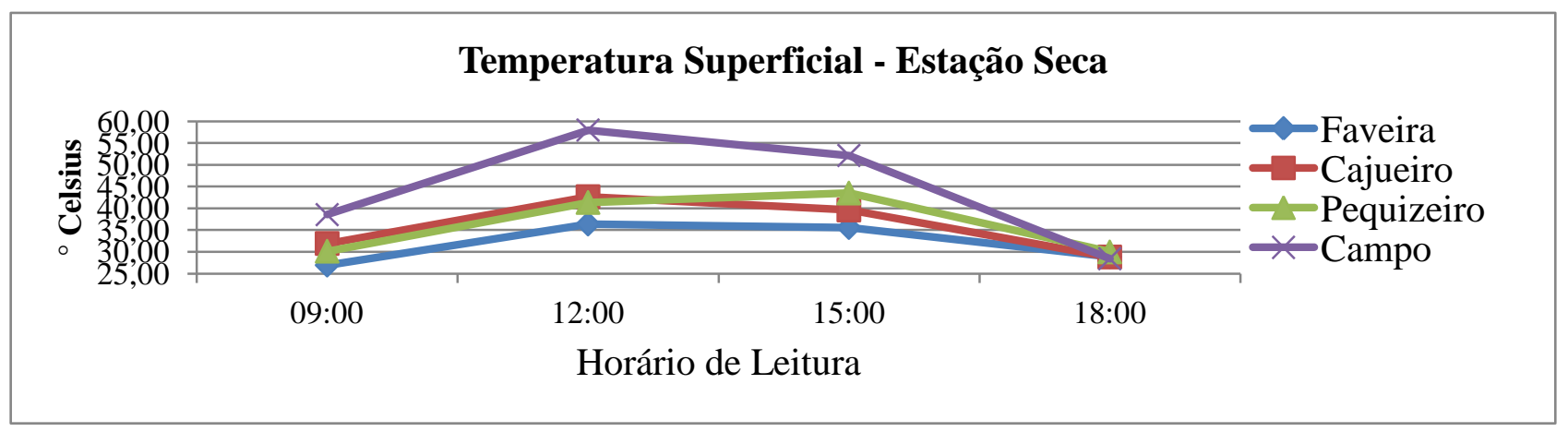

Gráfico 6. Umidade Relativa - Estação Chuvosa

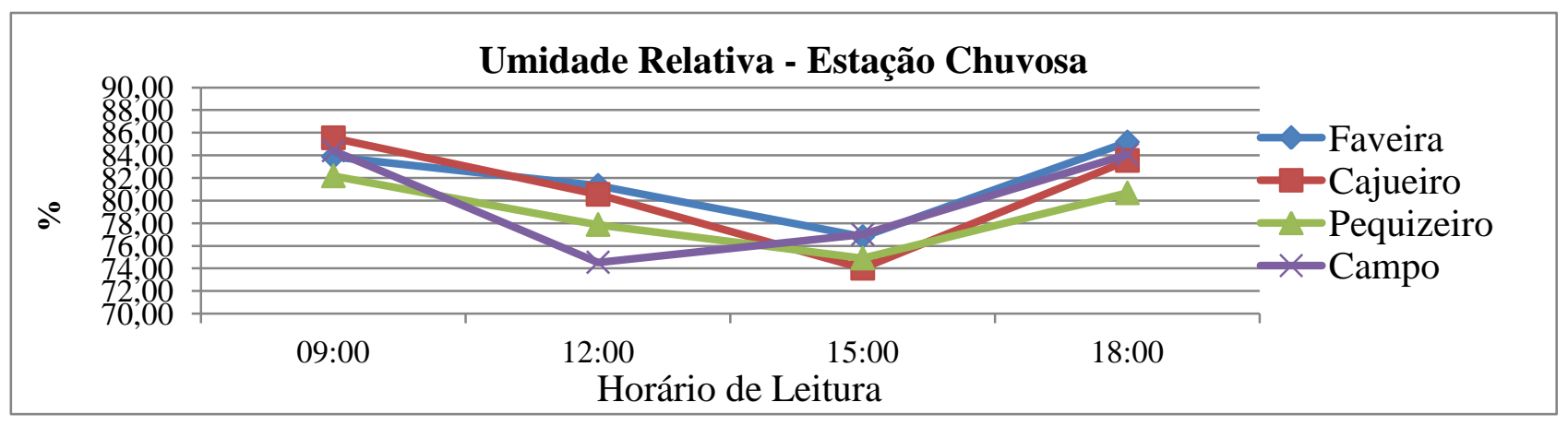

Gráfico 7. Umidade Relativa - Estação Chuvosa

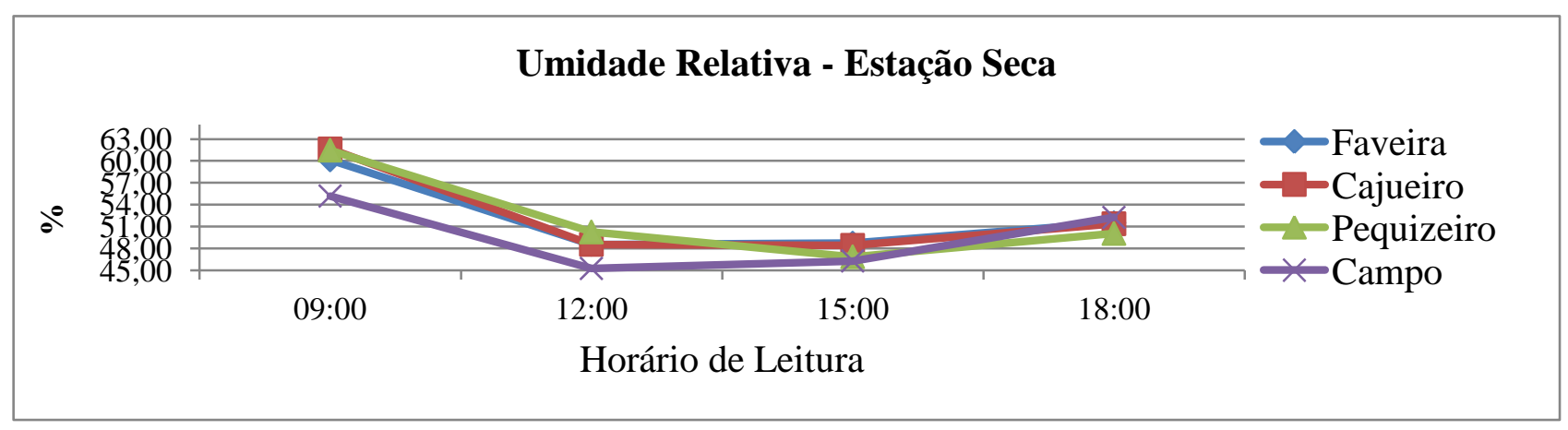

A temperatura superficial (Gráficos 4 e 5) demonstra que áreas sob influência da sombra de árvores tendem a ter uma temperatura inferior à áreas descobertas. No horário das $12 \mathrm{~h}$ é possível verificar diferença de mais de $3^{\circ} \mathrm{C}$, sob a Faveira em comparação com a área de campo aberto na estação chuvosa. Na estação seca essa diferença passa de $20^{\circ} \mathrm{C}$. Isso demonstra indícios de impactos positivos da vegetação urbana na melhoria das condições microclimáticas, principalmente na redução do calor. Dentre as espécies analisadas, a Faveira possui a melhor resposta para essa leitura.

Os índices de umidade relativa (Gráficos 6 e 7) sofrem alterações significativas durante o dia, com curvas de resposta semelhantes para todas as espécies. $\mathrm{Na}$ estação seca, o fato de existir alguma vegetação, 
independente da espécie assegura níveis mais altos de umidade relativa em comparação com o campo aberto. Apenas no final da tarde, o índice de umidade volta a se aproximar dos níveis de onde há vegetação.

A luminosidade (Gráficos 8 e 9) possui um comportamento bastante interessante. $\mathrm{Na}$ estação chuvosa, a faveira mostra uma maior luminosidade sob sua copa do que as demais árvores. Porém, na estação seca, o comportamento entre as espécies se mantém. Mais uma vez o campo aberto se mostra bastante desigual com maior diferença na estação seca. A luminosidade indica a quantidade de radiação que incide na superfície, a maior influência da radiação solar é na distribuição de calor. Pode-se observar que essa radiação é alta em campo às $15 \mathrm{~h}$ durante o período de seca, quando não há nenhuma nebulosidade, que somada à baixa umidade do ar, causa um grande desconforto. Pela quantidade de partículas de água em suspensão na época de chuva a radiação solar diminui, ou seja, num clima mais seco há maior incidência de radiação, como observa-se na comparação dos gráficos de luminosidade.

Gráfico 8. Luminosidade - Estação Seca

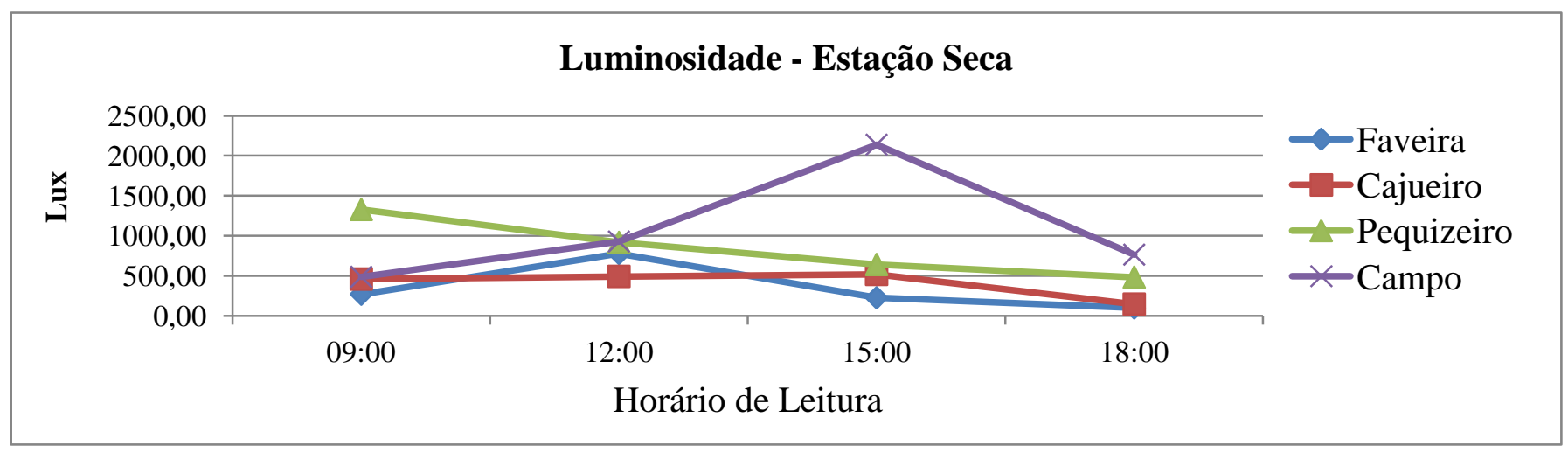

Gráfico 9. Luminosidade - Estação Chuvosa

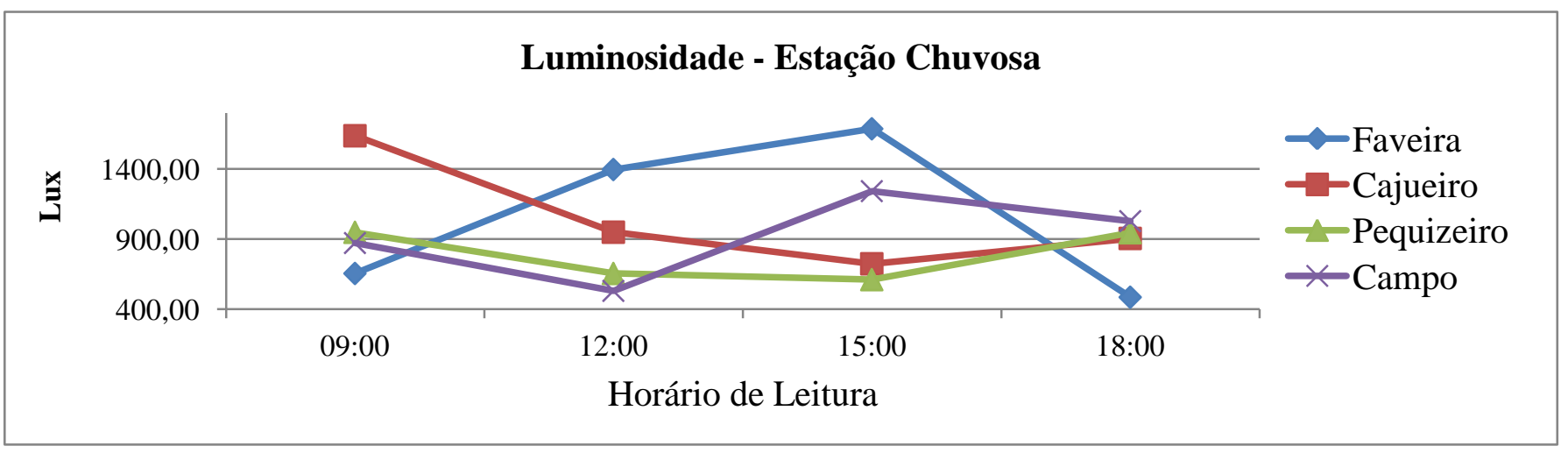

Outro fator importante é a característica que a Faveira tem de deixar que se tenha maior penetração da radiação durante os períodos chuvosos, permitindose assim, que sob sua copa se tenha maior luminosidade. Fenômeno interessante para mostrar como essa espécie é adaptada para o clima do Cerrado, mantendo sempre sob sua copa uma sensação térmica mais agradável. 


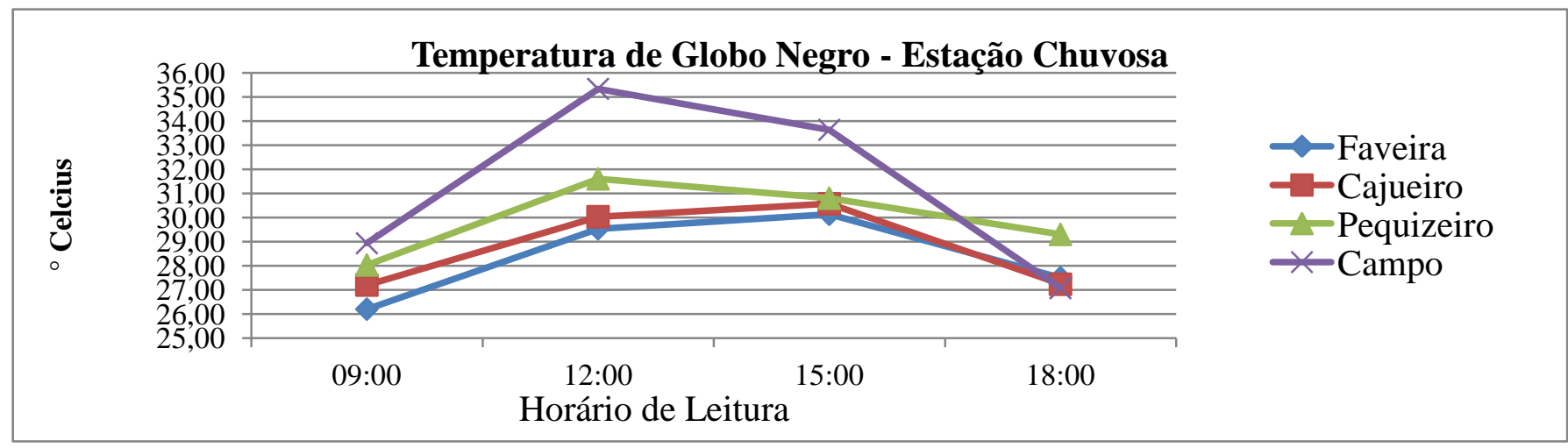

Gráfico 11: Temperatura de Globo Negro - Estação Seca

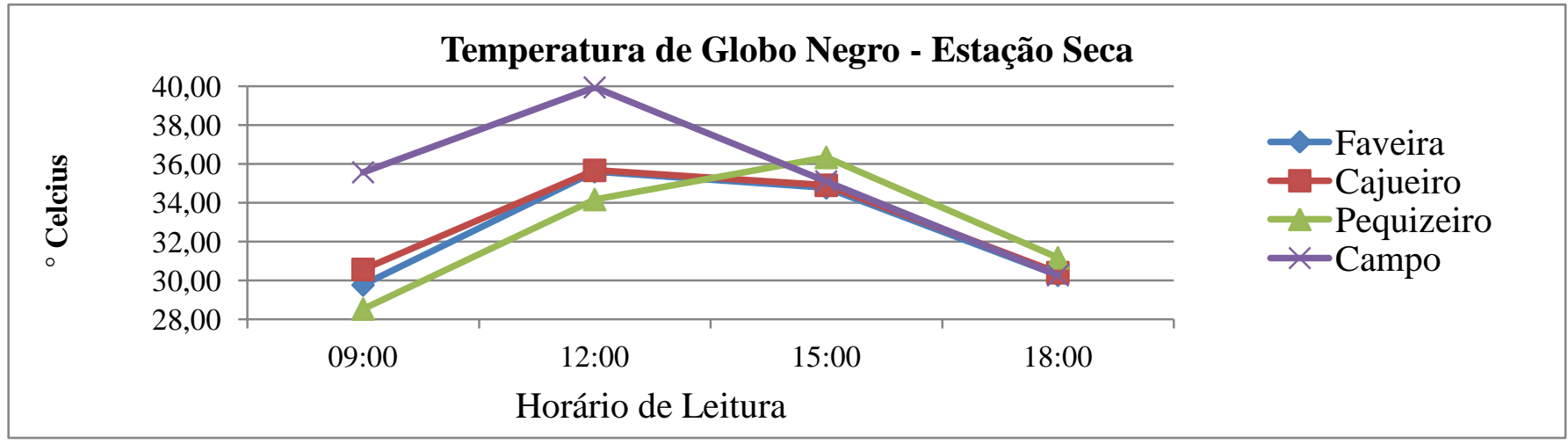

A temperatura de globo negro (Gráficos 10 e 11) indica os efeitos combinados da energia radiante, temperatura e velocidade do ar, fatores que influenciam no conforto térmico, dando resultado da sensação térmica sob essas condições. Pode-se perceber, por exemplo, que a sensação de calor numa mesma temperatura em épocas variadas do ano podem trazer efeitos diferentes. Isso ocorre porque a sensação do calor não é definida apenas pela temperatura do

A temperatura de globo de bulbo molhado (Gráficos 12 e 13) indica a temperatura do ambiente influenciado pela evaporação da água no ar, esse processo ocasiona o resfriamento ambiental. Essa é a temperatura que se sente quando a pele está molhada e exposta a movimentação do ar. Comparando os dados entre as estações chuvosa e seca, percebe-se um ambiente, mas pela umidade do ar, a velocidade do vendo, a radiação solar e fatores individuais como o metabolismo e a vestimenta. Com os resultados obtidos, é possível verificar que a sensação térmica em área sobre influência das árvores é diferente que no campo. A diferença de sensação térmica chega à aproximadamente $6^{\circ} \mathrm{C}$ às $12 \mathrm{~h}$, em época de chuva e à aproximadamente $8^{\circ} \mathrm{C}$ em época de seca, mais baixo sob vegetação em relação à área de campo aberto.

resfriamento mais rápido na estação seca devido a baixa umidade relativa do ar. 


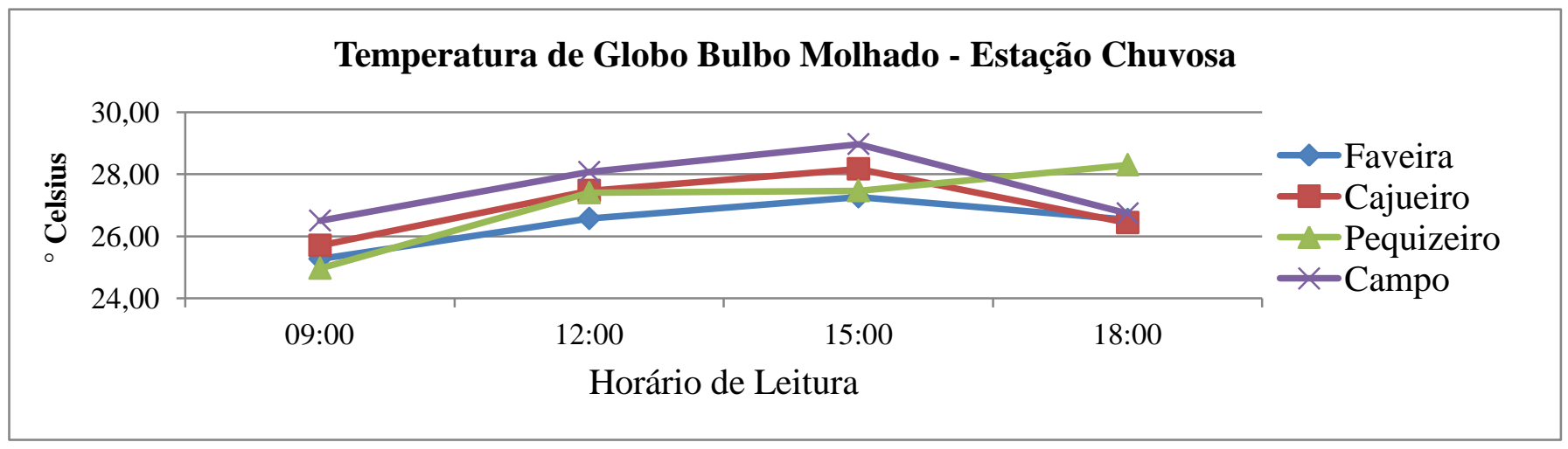

Gráfico 13: Temperatura de Globo Bulbo Molhado - Estação Seca

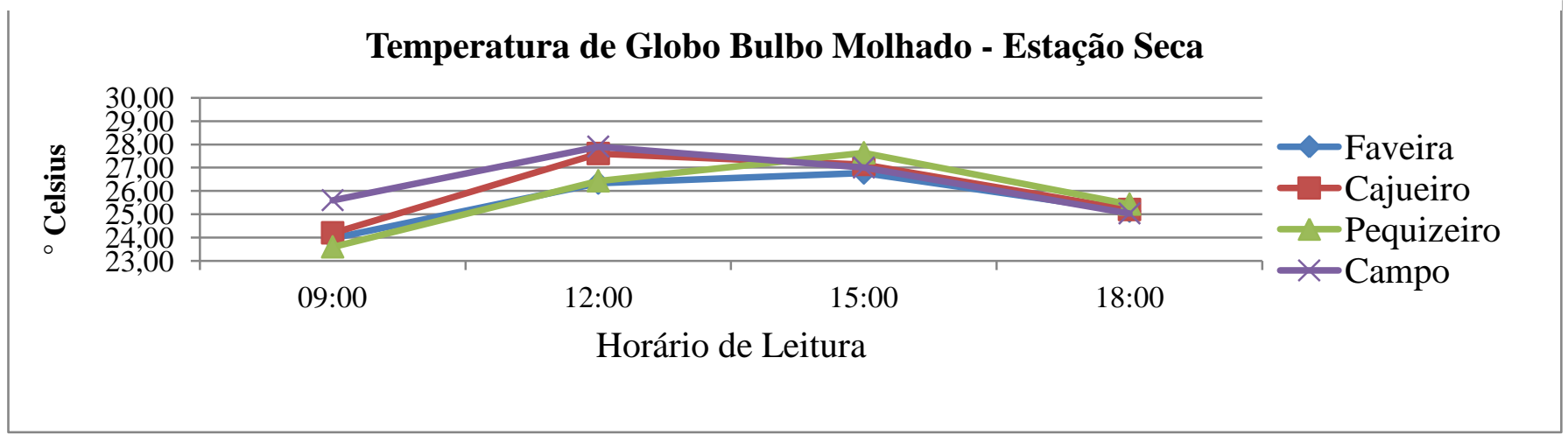

O movimento do ar na atmosfera, assim como a umidade relativa do ar, influencia diretamente sobre a temperatura e às sensações térmicas, pois ajuda a eliminar o suor e causar efeito de termoregulação da temperatura corporal, determinantes para as condições de conforto térmico e qualidade do ar. Percebe-se pelos gráficos 14 e 15 que a velocidade do vento é maior no horário em que a temperatura do ambiente $\mathrm{e}$ superficial é maior, às $12 \mathrm{~h}$, na estação chuvosa e às $15 \mathrm{~h}$, na estação seca, o que auxilia no processo de melhoria das condições de conforto.

A análise gráfica dos dados demonstra que a vegetação é fator determinante nas alterações de temperatura e umidade, características decisivas ao conforto ambiental. Comparando os resultados obtidos no monitoramento sob as copas das árvores e em campo aberto observa-se que a temperatura é mais amena nas primeiras áreas. Por tanto, os resultados obtidos nas medições indicam o valor da influência positiva da vegetação nos microclimas urbanos, sendo uma forma de amenizar os efeitos térmicos provocados pela urbanização.

Dentre as espécies analisadas, a Faveira se mostra como uma opção bastante interessante. $\mathrm{O}$ fato de esta espécie possuir uma copa densa e de grande porte, o que pode explicar os resultados obtidos.

Com os dados obtidos em campo foi possível realizar simulações computacionais através do programa EnviMet, para detectar as zonas de influência da arborização na área estudada e seu entorno. O programa foi desenvolvido por Bruse e Fleer em 1998 e serve para simular as interações microclimáticas no ambiente urbano, incluindo a simulação do processo de trocas térmicas entre superfícies, o fluxo de ar entre as edificações e turbulências, conforme especificações do site do programa. 


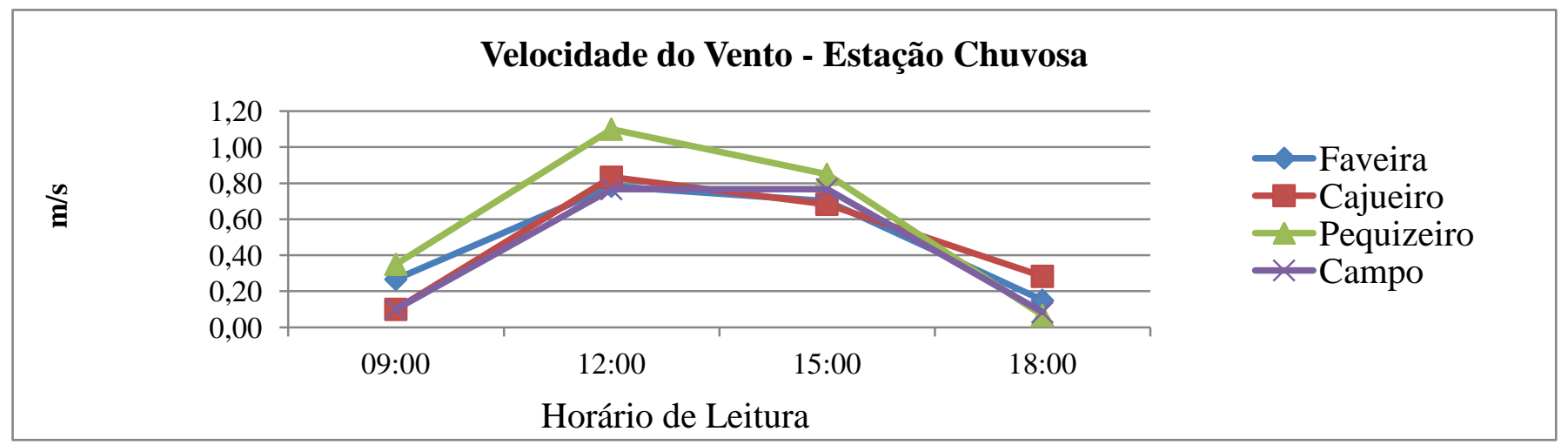

Gráfico 15: Velocidade do Vento -Estação Seca

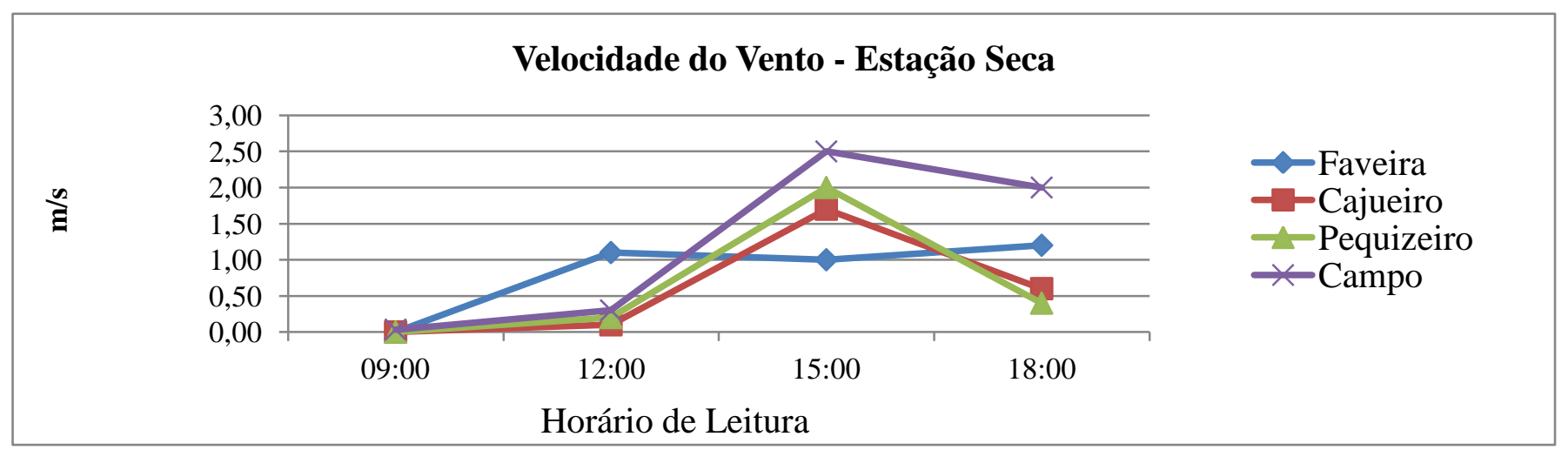

Para a simulação do ambiente estudado entrou-se com a imagem do Google Earth (Figura 4) da fração urbana estudada de 200 X 200 metros, com os dados obtidos na pesquisa de campo, além da direção do vento indicada pelo INMET (Instituto Nacional de Meteorologia), no ambiente computacional EnviMet. Para a visualização dos dados em mapas térmicos utilizou-se a extensão do EnviMet, o Leonardo 3. Para caracterização do terreno, foi utilizado uma grade de células de 4 X 4 metros. Nesta caracterização, foram definidos o tipo de solo e sua cobertura (cobertura vegetal, areia, concreto, asfalto), as vegetações de pequeno (10 metros), médio (15 metros) e grande porte (20

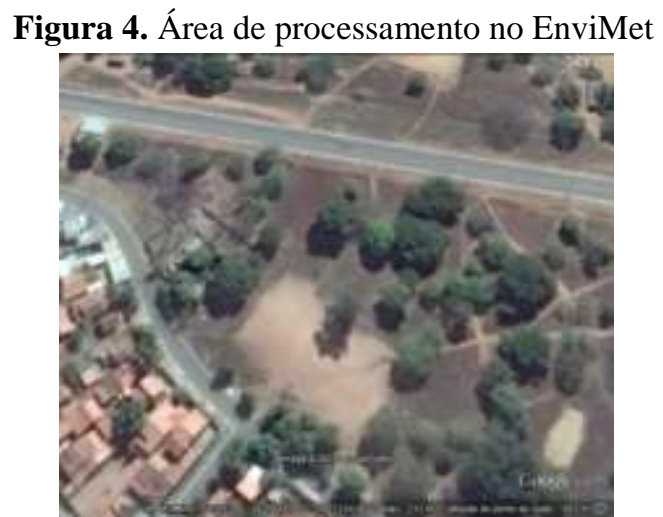

Fonte: Google Earth

Abaixo apresenta-se a simulação do Leonardo relativa à temperatura da área de estudo, na época de chuva, dezembro de 2014 (Figura 5) e na época de seca, junho de 2015 (Figura 6). metros) e edificações de 4 metros de altura com telhados. 


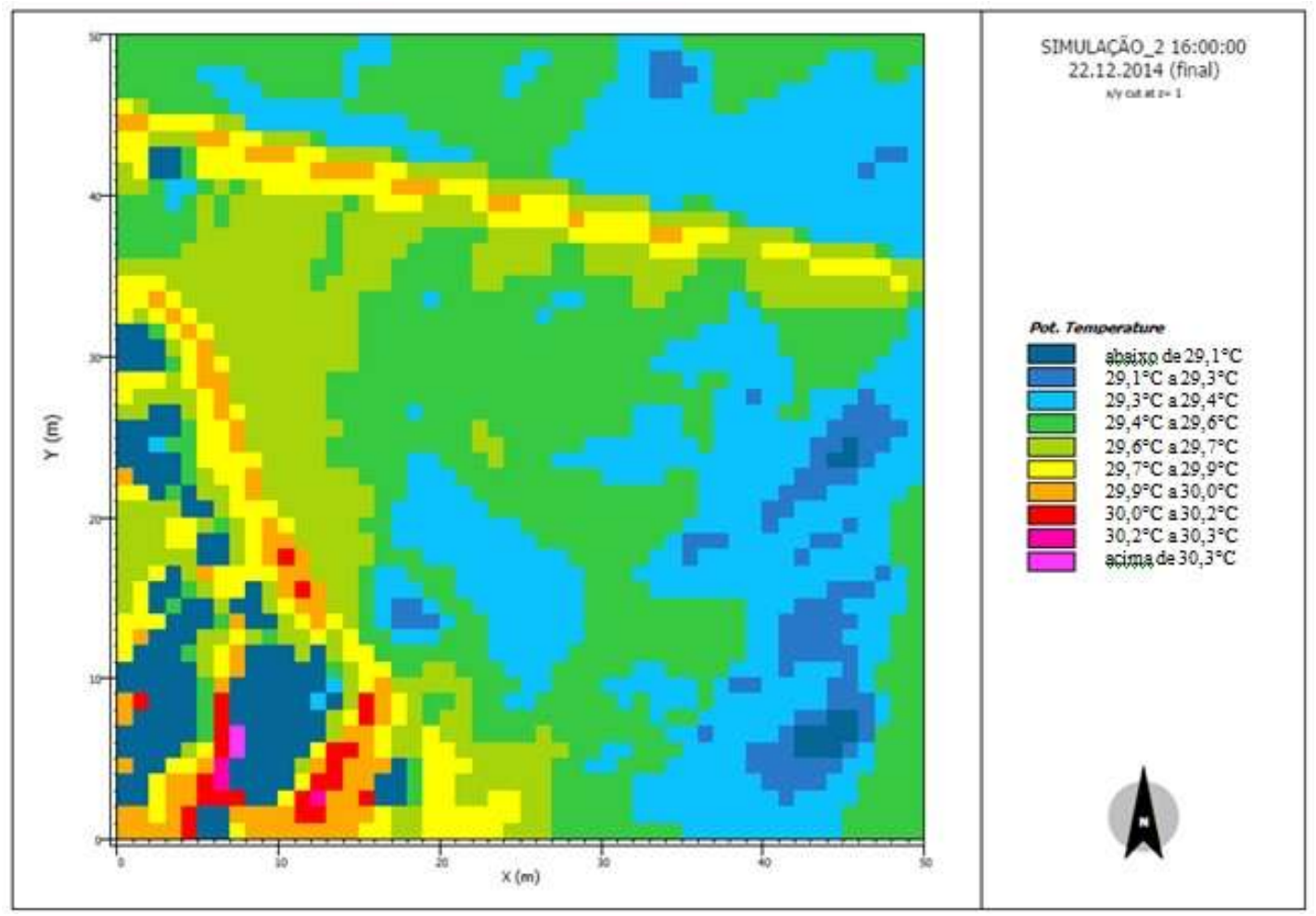

Figura 5. Simulação software Leonardo - Temperatura Ambiente - Época Chuvosa Fonte: O Autor

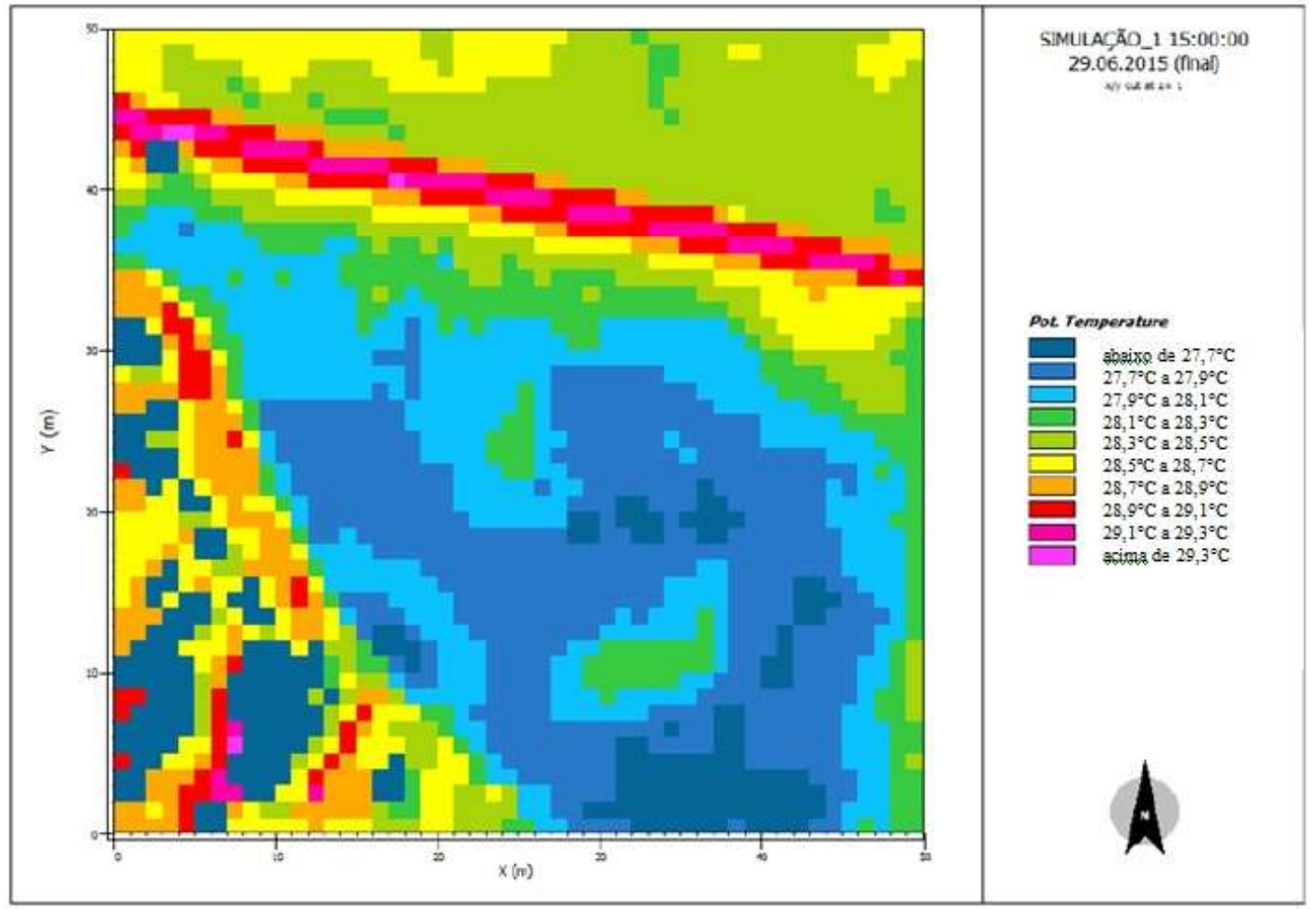

Figura 6. Simulação software Leonardo - Temperatura Ambiente - Época Seca Fonte: O Autor

Observa-se que nas áreas onde há arborização demonstrando a importância da arborização para a a temperatura é mais baixa e no asfalto a temperatura aumenta significativamente, em ambas as simulações. melhora do conforto climático nas cidades, Porém, na época de seca essa diferença é ainda maior, térmica é mais elevada. 
Outro ponto a ser destacado, refere-se à Umidade Relativa do Ar. Na Figura 7 visualiza-se a simulação na época chuvosa e na Figura 8, na época de seca.

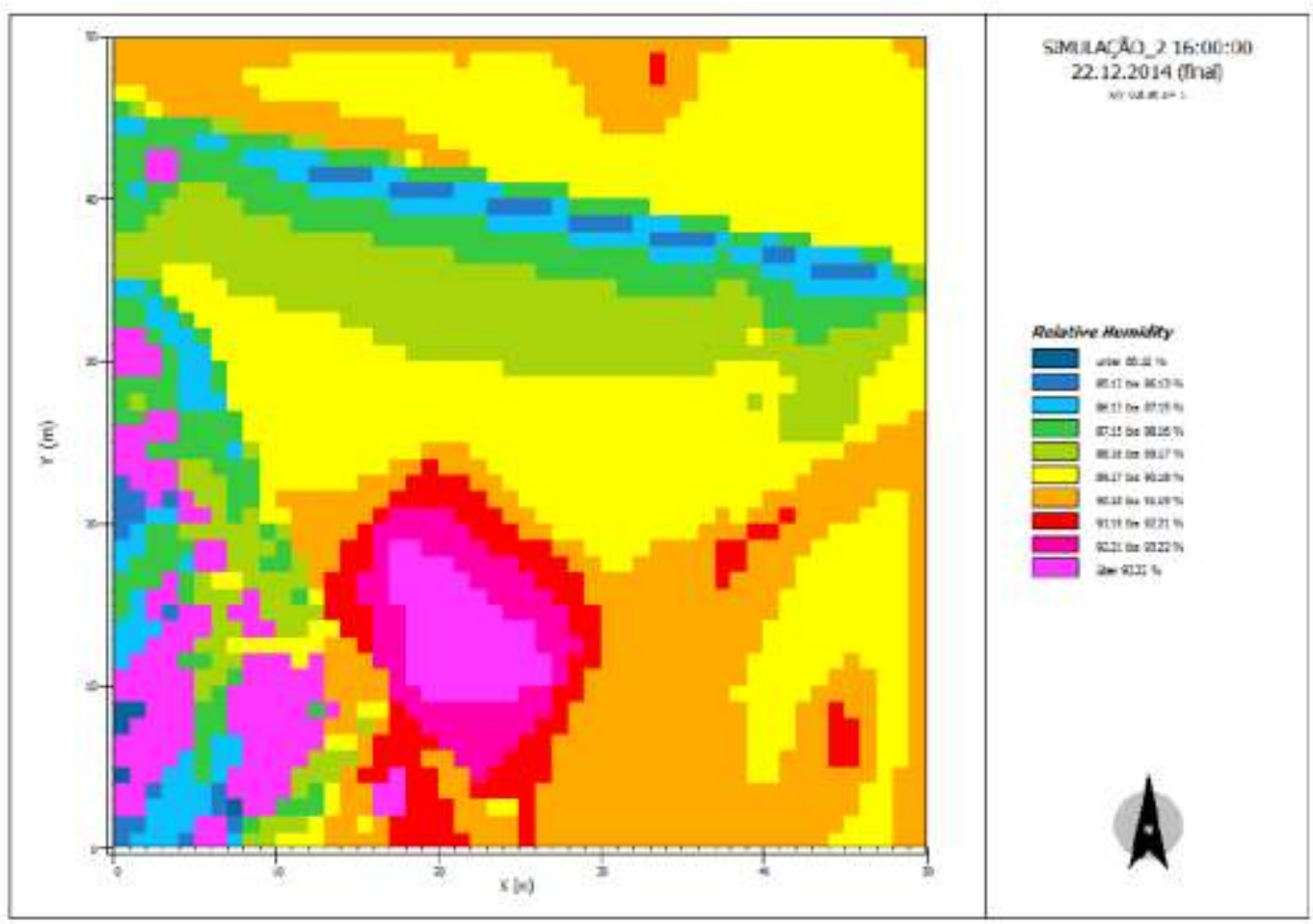

Figura 7. Simulação de Umidade Relativa do Ar - Época Chuvosa Fonte: O Autor

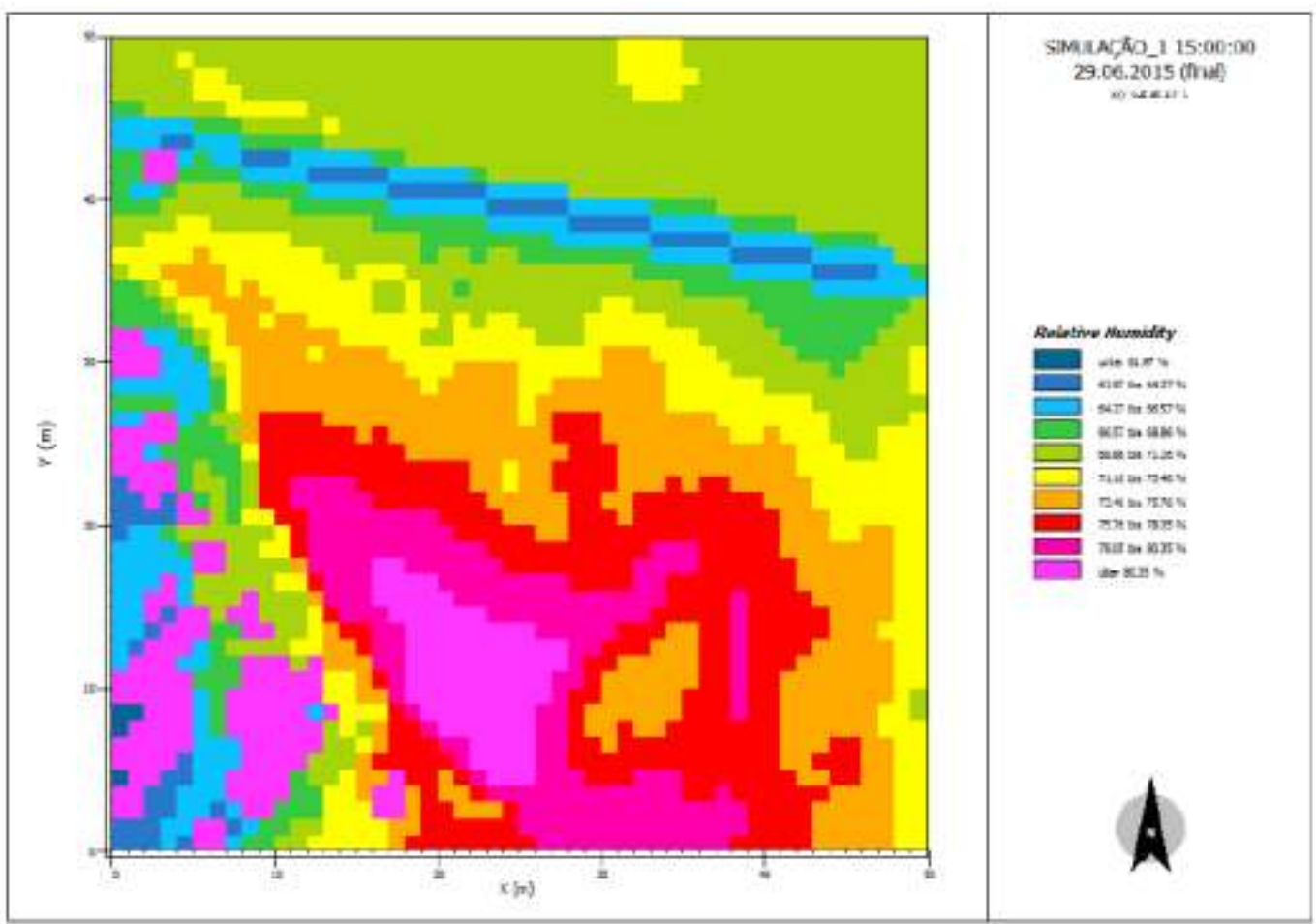

Figura 8. Simulação de Umidade Relativa do Ar - Época de Seca Fonte: O Autor 
Observa-se, principalmente na época de seca, que a umidade relativa do ar atinge níveis críticos mas, sob vegetação, mantêm-se mais alta. Com isso, é possível concluir a relevância da vegetação para a obtenção de ambientes confortáveis termicamente, pois a arborização colabora com a estabilidade microclimática, com a redução da insolação direta, redução da velocidade dos ventos, desempenhando um importante papel na melhoria da condição ambiental das cidades e melhora na qualidade de vida de seus habitantes.

\section{CONCLUSÃO}

A pesquisa se realizou de maneira satisfatória dentro do cronograma apresentado no Projeto Orientador. Aprofundamentos e discussões sobre o tema efetivam a pesquisa e mostram a demanda relacionada ao tema, visto que é de grande importância para a melhora do microclima na cidade de Palmas. Com a utilização do programa computacional Envi-Met foi possível o aprofundamento sobre a influência da vegetação na área estudada.

Desdobramentos da pesquisa podem ser sugeridos. Por exemplo o aumento de conforto térmico com arborização adequada em relação a ilhas de calor nas grandes cidades, o estudo das variáveis climáticas sob as mesmas espécies de árvores vistos nesta pesquisa sob outra condição, como por exemplo, próximo à locais construídos e com cobertura de asfalto ou concreto e crescimento dessa vegetação para indicação da melhor espécie para ser plantada em locais públicos ou privados.

\section{AGRADECIMENTO}

A realização desse trabalho foi possível ao apoio dado pela Universidade Federal do Tocantins, ao Laboratório de Conforto Ambiental do Curso de Arquitetura e Urbanismo da UFT coordenado pela professora Dra. Mariela Cristina Ayres de Oliveira que também orientou os estudos e à André Thomaz pelo apoio com os softwares utilizados nessa pesquisa, a todos meu sincero agradecimento.

Todos os autores declararam não haver qualquer potencial conflito de interesses referente a este artigo.

\section{REFERÊNCIAS}

GARTLAND, L. Ilhas de calor: como mitigar zonas de calor em áreas urbanas. São Paulo: Oficina de Textos, 2010.

\section{KRÜGER E. L.; MINELLA F. C. O. Ambiente Térmico De Uma Região Específica De Paris Situação De Verão. XII ENCAC, 2013}

MASCARÓ, Lucia Elvira Alicia Raffo de; MASCARÓ, Juan Luis. Vegetação urbana. Ed. Masquatro. Porto Alegre, 2002.

PANÃO, M.J.N.O.; Gonçalves H.J.P. P.; Ferrão M.C. Indicadores do Desempenho Térmico de Edificações Urbanas. 2006

OLGYAY, Victor. Arquitectura y Clima. Manual de Diseño Bioclimático para Arquitectos $\mathbf{y}$ Urbanistas. Barcelona, Editora Gustavo Gili Sa, 1963.

ROMERO, M. A. B. Princípios Bioclimáticos Para o Desenho Urbano. São Paulo: ProEditores, 2000.

SILVA, C. F. Caminhos bioclimáticos: desempenho ambiental de vias públicas na cidade de Terezina PI. 140 f. Dissertação (Mestrado em Arquitetura e Urbanismo) - Faculdade de Arquitetura e Urbanismo, Universidade de Brasília, Brasília, 2009. 